(The 3rd ICBS-2013)

\title{
THE EFFECT OF ORGANIC MATTER AND INDIGENOUS BACTERIA IN REHABILITATION OF EX- NICKEL MINE AREA
}

\author{
Sariwahyuni \\ Makasar Academy of Technical Industry, Ministry of Industry Republic of Indonesia \\ Jalan Sunu No. 220 Makassar \\ Email: srwahyuni4@gmail.com
}

\begin{abstract}
This research was aimed to examine the influence of organic matter and indigenous bacteria in rehabilitating the ex-nickel mine area. This research was conducted from August 2012to January 2013 at ex-nickel mine area PT Inco Sorowako South Sulawesi by means of splits plot design technique. Organic matter was set as the main plot and phosphate solvent bacteria, metal reducing bacteria were set assubplotandsub-subplot respectively. Organic matter $400 \mathrm{~g} / \mathrm{polybag}(19 \mathrm{ton} / \mathrm{ha})$, Pseudomonasaeruginosa $2 \times 10^{6} \mathrm{cells} / \mathrm{ml}$ and Bacillusmegaterium $2 \times 10^{6} \mathrm{cells} / \mathrm{m} /$ with a dose of $20 \mathrm{ml} / \mathrm{plant}$ were able to reduce the concentration ofNi(II) by $25.83 \%$, increasephospat availability $42.355 \%$, increase thesoilpH from 4.19 to $7.5(44.13 \%$ ) and provide improvedseedsweight $100 \%$.
\end{abstract}

Key words: Organic matter, indigenous bacteria, Nickel toxicity and Phosphate availability

\section{INTRODUCTION}

The development of industrial activities in certain parts of Indonesia has shown a significant growth. The abundant natural resources potential posessed by this country can be managed and converted into high economic value products. However, industryial developments need to consider the environment sustainability to support the industrial activities.

The total area and climate potential of Indonesia are capable in supporting the mining industry. Most of land area of Indonesia consists of parent soil which is derived fromdecaying host rock. Climate exposure alternating between rainy season and dry season has speed upthe process of the mineralization of the bedrock. Thereforeits has the potential to be further exploited. Total area of decaying land area is approximately $67 \%$ of the total land area in Indonesia (Nursyamsi, 2008).

The nickel mining activitiesoperated by PT. INCO Sorowako is carried out in the Luwu district. The area of exploitation concession rights which is given to PT INCO Sorowako consist of 1000 hectares (Luwu Statistics, 2012). However, those total areas are not mined simultaneously due to ore concentrations on certain areas are economically inefficient to be explored.

It is found nickel $\mathrm{Ni}$ (II) with concentration between 3-5\% spreading in old laterit soil. These concentration value of $\mathrm{Ni}$ (II)comprises with internationalstandard of nickel mining. Bedrock containing nickelaccording to international trade standards are found at a depth of 20-40 m below the ground surface. Layer of soil and vegetation must be removed or excavated to reach these rocks. The excavated soils are stacked around the mine area, and will be backfilled after mining activity is completed. Former topsoil layer heap region become a new potential agricultural areas which in turn has the potential to improvee the Luwu district domestic product. 
The current pproblems facing by local goverment are how to utilise of ex-mined land that to be more productive. The decaying soil ccause the dissoving of mineral, metals and other elements. Therefore, soil becomes reactive (sensitive) and has a level of erosion and high leaching (leaching). Bartholomew (1972) in Sariwahyuni (2000) states that leaching is a major cause of fertility problems, because of leaching in the soil can cause a decrease in soil pH.

Before considering the ex-mining land to be cultivated the potential of the land itself need to be taken into account. The approach used to determine the resource potential of an area is the assessment of the land capability class, which is limited by the shape and the slope. Tthese factors mainly refers to the degree of difficulty in land management and protection measures to prevent erosion and landslides. In fact many areas in the form of a flat area has obstacles that require complex analysis and solutions before it can be cultivated or utilised.

The consentration of minerals on nickel mined lands shows significant variation. $\mathrm{PH}$ or acid soil condition, the content of $\mathrm{Ni}$ (II) and other associated minerals that are in the same group with the Ni (II) shows a high concentration. Therefore, if the land is aimed for agriculture purposes then it will be possible as a limiting factor in agricultural production process. Tan (1998) stated that an important factor to notice on acid soil is heavy metal poisoning, and the formation of low solubility level salts that directly reduce the productivity of the soil. To gain information about the possibility of heavy metal poisoning Ni (II) and macro minerals bonding such as fospat by heavy metals that cause the low solubility or availability of fospat. Research has been done on nickel mined land with varying degrees of treatment by application of organic manures, Bacillus megaterium and Pseudomonas aeruginosa. Organic materials have a variety of functions such as the release of nutrients as well as the creation of a better soil physical condition for example improvements of $\mathrm{O} 2$ aeration allows more current cycle. The other function is to raise the $\mathrm{pH}$ to increase the availability of phosphate, while the Bacillus megaterium and Pseudomonas aeruginosa bacteriasare able to reduce heavy metals and dissolvee thephosphate.

This study was aimed to examine the relationship of organic matter, phosphate and solvent bacterial metal reducing bacteria in rehabilitation of nickel mined area.

Research rresults and data analysis shows that this study is able to improve the productivity of mined nickel area of PT. INCO Sorowako. This condition will increase the income, create diversity of income sources, jobs opportunity and increasedagricultural business revenue of local people in Luwu district.

\section{MATERIALS AND METHODS}

The research was conducted in August 2012 - January 2013 in Microbiology Laboratory at Akademi Teknik Industri Makassar, Faculty of Medicine Hasanuddin University, Faculty of Agriculture and Green House UNHAS. This study was conducted in three stages: (1) The laboratory scale for isolation, identification and breedingprocess ofbacteria, (2) The Green House Scale for trials on crops, (3) agro-climate testing in the Village area of bacterial origin Pongkeru District Malili East Luwu . 
The experimental design of Green House scale used the split- split plots design with organic matter as the main plot (B; B0: without organic matter, B1; $200 \mathrm{~g} /$ polybag, B2; $400 \mathrm{~g} /$ polybag), Bacillus megaterium as solvent fosphat bacterium which allocated as a subplot (P; P0: Without Bacillus sp, P1; $10 \mathrm{ml}$ / polybag, P2; $20 \mathrm{ml} /$ polybag) and Pseudomonas aeruginosa as adsorptions bacteria for metal (C; C0: Without Pseudomonas sp, C1; $10 \mathrm{ml} /$ polybag, $\mathrm{C} 2 ; 20 \mathrm{ml} /$ polybag) is used as a child plots. The populations of these bacteria are $2 \times 106$ cells $/ \mathrm{ml}$.

The parameters used are $\mathrm{pH}, \mathrm{P}$ and $\mathrm{Ni}$ (II) soil, while the plant parameters used are weight of crop seed. Data analysis was performed with software SPSS 19.Ssignificant different from the results of analysis will be further tested with multiple ranges by Duncan's at 5\% level (Gomez and Gomez, 1995).

\section{RESULTS AND DISCUSSION \\ Soil Microorganisms}

Identification of soil microorganisms especially bacteria for reducing $\mathrm{Ni}$ (II) and phosphate solvent bacteria wereperformed to obtain isolate bacteria that was used in this study. The identification process wasconducted starting from the isolation process, the test of resistance to $\mathrm{P}$ and $\mathrm{Ni}$ (II), reduction ability test to $\mathrm{Ni}$ (II) and the solubility of. These processes acquired two indigenous bacterial species wich wereBacillus megaterium and Pseudomonas aeruginosa. The isolated bacteria wascultured for use as treatment with organic matter in the green house.

\section{$\mathrm{pH}$ and Available $\mathrm{P}$ in the soil}

The use of organic matter combined with solvent metal bacteria and phosphate solvent bacteria can increase $\mathrm{pH}$ of soil with range of 4 to 7.5 .

\section{$\mathrm{pH}$ of soil in10 WAP (ppm)}

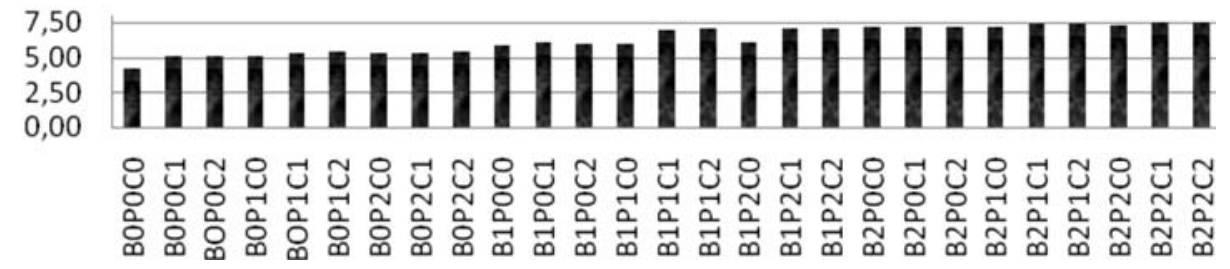

Figure 1. pH of Soil in 10 Week after Planting (WAP)

The addition of organic matter in the soil caused by the adsorbed metal-OH groups contained in the organic matter. $\mathrm{OH}$ group can formed bonds $\mathrm{OH}$-heavy metal. In a simple bonding that occurs is as follows:

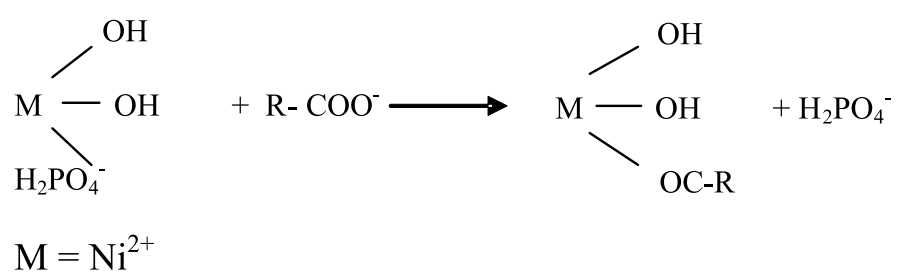


Phosphate solvent bacterial activity plays a role in the process of mineralization or decomposition of the compounds are adsorbed phosphate by heavy metals in the form of $\mathrm{Al}_{2} \mathrm{HPO}_{4}, \mathrm{Al}\left(\mathrm{PO}_{4}\right)^{2}, \mathrm{FePO}_{4}, \mathrm{MgPO}_{4}$ or other forms of bonding between the metal and phosphate commonly found in acid soils.

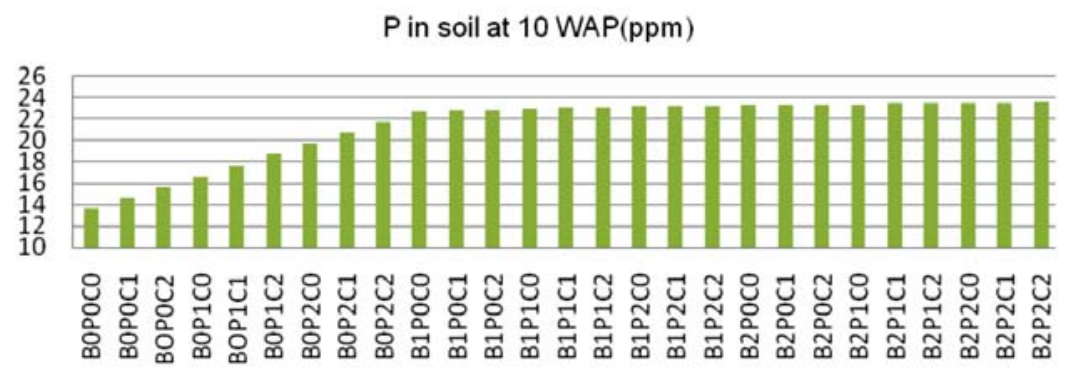

Figure 2.Availability of $P$ in Soil.

Availability of $\mathrm{P}$ in soil is directly proportional to the $\mathrm{pH}$ value of the soil. On neutral soil $\mathrm{pH}$ conditions, the concentration of cations and anions in the soil solution is balanced so that the solubility of metals such as $\mathrm{Al}, \mathrm{Fe}, \mathrm{Mg}$, and other base cations become inactive, therefore, the element of $\mathrm{P}$ became available, $\mathrm{P}$ is not adsorbed by metal or other base cations. Instead of solely depend on the soil pH, P availability is also depends on the presence of metallic elements in the soil. Metallic elements are known as elements that not mobilein the ground which can substitute $\mathrm{Fe}$ and $\mathrm{Mg}$ ions of the clay mineral lattice. Therefore,the more metal occupy lattice clay minerals then content of $\mathrm{Fe}$ and $\mathrm{Mg}$ available in soil solution increased. Due to increasing content of $\mathrm{Fe}$ and $\mathrm{Mg}$, the amount of $\mathrm{P}$ adsorbed in the bond of $\mathrm{Fe}-\mathrm{P}$ and $\mathrm{Mg}-\mathrm{P}$ is also more and more which is reduce the availability of $\mathrm{P}$ in the soil. The use of organic materials that may produce humid acids with-OH group can disable the solubility of $\mathrm{Al}, \mathrm{Fe}$, and other heavy metals to form metal-OH bonds which causes the metal cations to be inactive in the soil. By deactive the metal cation, more $P$ element available in the soil. The process increasing availability of phosphate in organic soil is possible with the help of fospatase enzymes produced by plant roots and the high level of microorganisms such as bacteria Bacillus sp and Pseudomonas sp. Eenzymatic reaction principle of fospatase is hydrolysis which releasephosphate ions from organic $\mathrm{P}$ compounds.

\section{$\mathrm{Ni}$ (II) in Soil}

Soil types found in the experiment location that was similar to Oxisols characteristics and Redsoil Podzols soil. Nickel content was measured from the soil samples aproximately $576.450 \mathrm{mg} / \mathrm{kg}$. This value is quite high considering that the general content of $\mathrm{Ni}$ in soil is normally between 5-500 ppm (Jenkins et al., 2008). The use of organic matter $400 \mathrm{~g} / \mathrm{polybag}$ combined with phosphate solvent bacteria and adsorption metal bacteria with a concentration of $20 \mathrm{ml}(2 \times 106$ cells / $\mathrm{ml})$ was able to decrease the concentration of $\mathrm{Ni}$ (II) down to $427.572 \mathrm{mg} / \mathrm{kg}(25.83 \%)$ at 10 WAP.

Humid acids are able to interact very strongly with various metals to form metal complexes of humid, that affected the adsorption-desorption properties of the metal. Humic acids are organic substances that have functional groups such as $-\mathrm{COOH},-\mathrm{OH}$ and-OH phenolic alcoholates, hence, humic acid has a chance to bind to metal ions because these 
groups can undergo deprotonation at a relatively high $\mathrm{pH}$. The use of organic materials and metal reducing bacteria can disable $\mathrm{Ni}$ (II) in the soil solution as $\mathrm{Ni}$ (II) absorbed in organic matter after reduced by heavy metals adsorbtion bacteria.

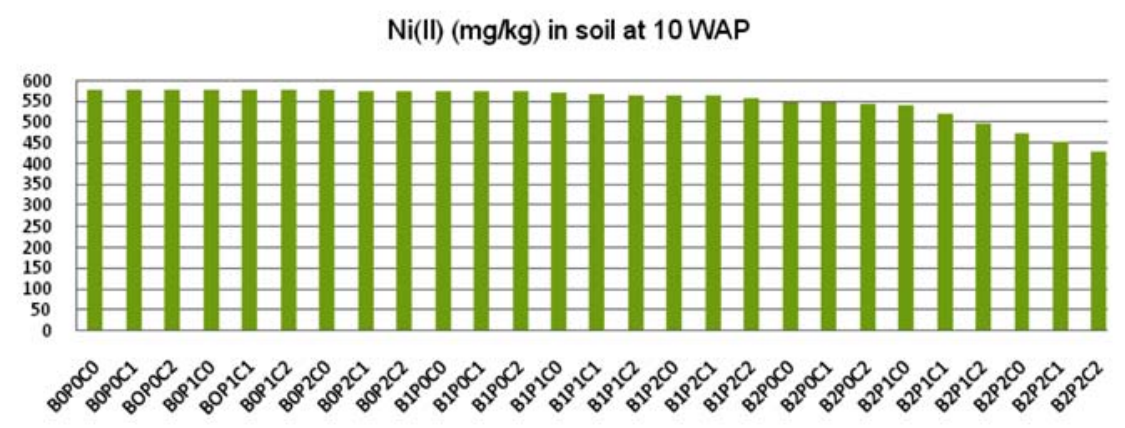

Figure 3. Nickel in Soil

Tan (1998) stated that humic acid is effective in binding micronutrients such as $\mathrm{Cu}, \mathrm{Zn}$, and $\mathrm{Mn}$. In addition, humic acid can also provide nutrients like N, P and $S$ into the soil and energy to support the activities of microorganisms (Stevenson, 1994). Janick et.al (1990) explains that the fixation of $\mathrm{Ni}$ (II) can be found commonly in soil that has plenty of organic matter and a major cause of $\mathrm{Ni}$ (II) deficiency of the soil. In contrast, the soils that contain low organic matter, the availability of $\mathrm{Ni}$ (II) are often found in the clay mineral lattice. The higher concentration of clay in the soil, the more the metal is bound to the clay minerals.

\section{Crop Production}

Treatment of providing organic matter $400 \mathrm{~g}$ / polybag (B2), combined with fospat solvent bacteria2 $\times 106$ cells / $\mathrm{ml}$ (P2), and metal metal reducing bacteria $2 \times 106$ cells / $\mathrm{ml}$ (C2) gives the best effect on seed at 10 WAP.

Nutrients are needed in the formation and growth of vegetative and generative organs, one of which is an element of $\mathrm{N}$. Availability of $\mathrm{N}$ in the soil can be either $\mathrm{NO}_{3}$ and $\mathrm{NH}_{4}{ }^{+}$ derived from organic matter which is broken down by bacteria through nitrification and amonifikation, hence plants can absorb and support vegetative growth. Higher rod is generally followed by the development of other organs such as leaf area that serves as a catchment area of sunlight that will affect the process of photosynthesis. Results of the process of photosynthesis in the leaves will flow to all parts of the body through the plant phloem tissue and tissue-forming stem will be on juvenile phase, vegetative plants and a plant when the seed has entered the production phase.

weight of seed in 10 WAP $(\mathrm{g})$

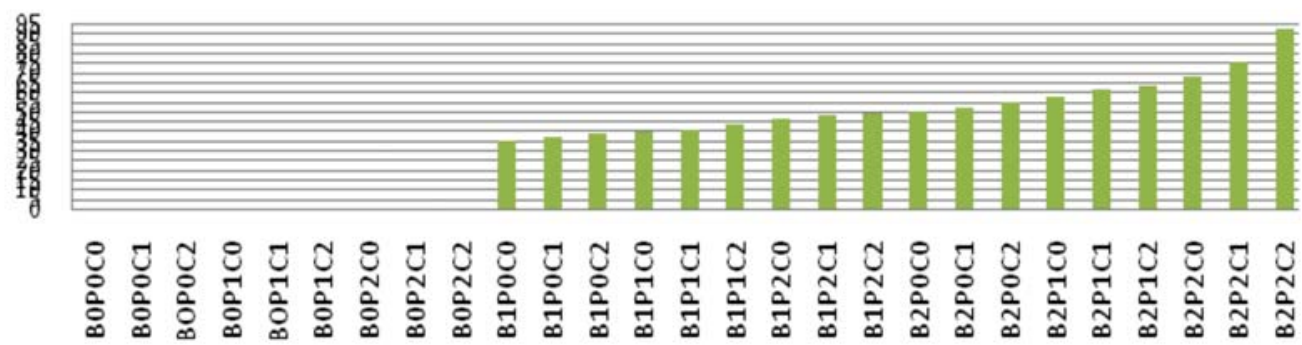

Figure 4. Weight of seed/cobcorn 
Mashum et al. (2008) stated that some acidic compounds produced by bacteria have a higher affinity than orthophosphate on some heavy metal cations, consequently phosphate liberated into the soil solution into a form available to plants.

The high concentration of metal can make a fixation of $P$, consequently $P$ is less available. $P$ element is the major component constituents of ribonucleic acid and deoxyribonucleic (RNA and DNA) that form esters with phosphate. This is an important compound in all living things. Lack of $P$ available to the uptake $P$ in plant will increase energy deficiency needed for other growth activities, including the growth of vegetative and generative plant organs. The existence of the purple color in the leaves indicate that the plant is suffer fromP deficiencycy, consequently, ATP (adenosine trifospat) which is the energy required to break down starch is not available, resulting in accumulation of carbohydrates in the leaves and stems of plants. P elements play a role in the sugar reform process in the form of ATP, sugar will be broken to provide energy indeveloping a new plant cells and tissues.

\section{Productivity in the Experiment Field}

Field application had shown that without treatment can only yield corp production about 0,094 tons/ $\mathrm{Ha}$, whereas a given treatment plant was able to achieve production of up to 4.24 tonnes $/ \mathrm{Ha}$. This indicates that the application of organic matter $400 \mathrm{~g} /$ plant, Bacillus megaterium $2 \times 10^{6} \mathrm{cells} / \mathrm{ml}$ up to $20 \mathrm{ml} /$ plant, Pseudomonas Aeruginosa $2 \times 10^{6} \mathrm{cells} / \mathrm{ml}$ up to $20 \mathrm{ml} /$ plant able to increase the corp production up to $97.78 \%$.

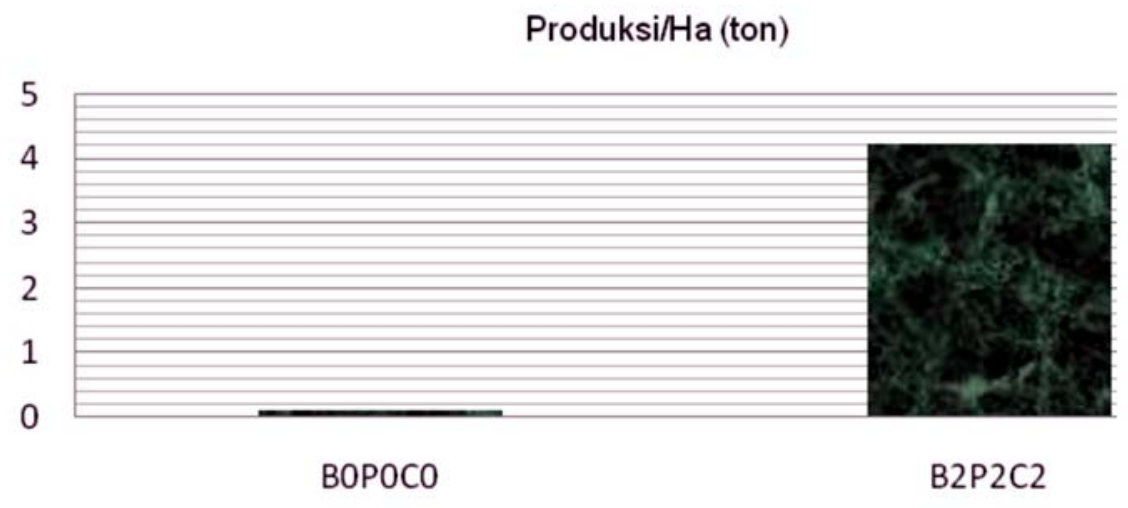

Figure 5. Production of corn in the field

\section{CONCLUSION}

Application of organic matter with a dose of $400 \mathrm{~g} /$ polybag (B2) or the equivalent of 19 tonnes/ha, Bacillus megaterium $2 \times 10^{6} \mathrm{cell} / \mathrm{ml}$ at a dose of $20 \mathrm{ml} / \mathrm{plant}$ (P2) and Pseudomonas aeruginosa $2 \times 10^{6} \mathrm{cells} / \mathrm{ml}$, were able to increase the availability of fospat from 13.633 ppm to 23.650 ppm or increase the phosphate content availablilityabout $42.355 \%$, reducing the concentration of $\mathrm{Ni}$ (II) from $576.450 \mathrm{mg} / \mathrm{kg}$ down to $427.572 \mathrm{mg} / \mathrm{kg}$ (25.83\%), Increase the soil $\mathrm{pH}$ from an average of 4.19 to $7,5(44.13 \%)$, giving an average increase in weight of seed cob corn plants from $0 \mathrm{~g}$ to $92.085 \mathrm{~g}(100 \%)$. Field application showed that the corn crop production increased up to $97.78 \%$. 


\section{Suggestion}

Nickel mined land rehabilitation like in ex-mined area of PT. INCO Sorowako can be done by applying organic matter, Bacillus megaterium and Pseudomonas aeruginosa at a dose of 19 tonnes $/ \mathrm{Ha}$ of organic matter and $20 \mathrm{ml} /$ plant with a population of $2 \times 10^{6} \mathrm{cells} / \mathrm{ml}$ for each Bacillus megaterium and Pseudomonas aeruginosa. Further studies areneeded to find models of cheap biotechnology and easily applied by people, especially in the process of bacterial culturization.

\section{REFERENCES}

Gomez. K.A., and. A. Gomez., 1995. Statistical Procedures for Agricultural Research.Second edition. University of Indonesia.

Janick, J., R.W. Schery, F.W. Woods, and V.W. Ruttan, (1990) Plant science: An Introduction to World Crops. W.H. Freeman, San Francisco.

Jenkins, R.D., J. West-Thomas, C. Affstrom. 2008. The Effect of humic substances on Ni (II) on vermiculite adsorbtion. Chem. Lett. 1, 65-77.

Ma'shum, M., J. Soedarsono, and L. Endang. 2008. Biologi Tanah. Pasca Sarjana UI. Jakarta.

Nursyamsi, D., S.M. Nanan., Sustini dan I.P.G. Widjaja-Adhi. 2008. Serapan P untuk Tanaman Pangan pada Tanah-tanah Masam.Jurnal Tanah Tropika. 4; pp 34-41. Pusat Penelitian Tanah dan Agroklimat Bogor.

Sariwahyuni, 2000, Laju Penjerapan Logam berat Cu, Cd, Co dan Ni dengan penambahan Bahan Organik Ganggang coklat pada tanah Bekas Penambangan Nikel Pomalaa, Thesis S2 Program Pasca Sarjana, Universitas Hasanuddin, Makassar.

Stevenson, F.J. 1994. Humus Chemictry, Genesic, Composition, Reactions. A WileyInterscience and Sons. New York. 496 pp.

Tan, K.H. 1998. Principle of Soil Chemistry. Third Edition Reviced and Expanded Marcel Decker Inc., New York 